\title{
EFFICACY OF LEMON GRASS (CYMBOPOGON CITRATUS) ON THE HIDE BEETLE (DERMESTES MACULATUS) IN SMOKE-DRIED AFRICAN CATFISH (CLARIAS GARIEPINUS) IN JOS NORTH LGA OF PLATEAU STATE, NIGERIA
}

\author{
Ishaya M. ${ }^{1}$, John W.C. ${ }^{1 *}$, Oke O. ${ }^{1}$, Chomini M.S. ${ }^{2}$, Oladejo A.O. ${ }^{1}$, Ihum T.A. ${ }^{3}$, \\ Olorundare O.O. ${ }^{1}$, Ukanyirioha C.J. ${ }^{2}$, Ayorinde J.O. ${ }^{1}$, Sikiru G.K. ${ }^{1}$ \\ ${ }^{1}$ Department of Pest Management Technology, Federal College of Forestry Jos, Nigeria \\ ${ }^{2}$ Department of Forestry Technology, Federal College of Forestry Jos, Nigeria \\ ${ }^{3}$ Nigeria Stored Products Research Institute, Ilorin, Nigeria \\ ${ }^{\star}$ E-mail: jowaltee@gmail.com
}

\begin{abstract}
Fish losses to Dermestes maculatus infestation is one of the biggest problems of fish farming, hence this study was carried out to evaluate the efficacy of Cymbopogon citratus against Dermestes maculatus fed on smoke-dried Catfish. Fresh and Dermestes maculatus infested samples of Catfish were procured. The fresh Catfish were smoked traditionally and then oven dried at $60^{\circ} \mathrm{C}$ for 1 hour to remove excess moisture. Twenty-eight of un-infested Catfish were placed in $1000 \mathrm{~mL}$ plastic jars and Cymbopogon citratus powder was added at the rate of $2.5 \mathrm{~g}, 5.0 \mathrm{~g}, 7.5 \mathrm{~g}$, and $10.0 \mathrm{~g}$. The fish and the powder were thoroughly mixed and six newly emerged adults were introduced into each jar, while to a different set of experiment, six $3^{\text {rd }}-4^{\text {th }}$ instar larvae of Dermestes maculatus were introduced into each jars and then covered with muslin cloth. The experiments were arranged in a Completely Randomized Design with each treatment replicated three times. Data on mortality of the larval Demestes maculatus was collected for 21 days while data on adult mortality was collected for 7 days at 48 hours interval. The data were subjected to ANOVA and means were separated using Duncan multiple range test. Cymbopogon citratus powder showed significant effects on Dermestes maculatus larvae and adult, where the highest mortality was recorded at the following doses of 2.5 and $5.0 \mathrm{~g}(72.2 \%$ and $77.8 \%$ respectively) for the larvae and 5.0 and $10.0 \mathrm{~g}(22.2 \%$ and $16.7 \%)$ for the adults. This study revealed that Cymbopogon citratus has insecticidal potentials and therefore, be used to preserve Catfish shelve life.
\end{abstract}

\section{KEY WORDS}

Demestes maculatus, Cymbopogon citratus, catfish, Clarias gariepinus, lemongrass, mortality, larva.

The current world population is over seven billion people and it has been projected to increase to above nine billion by 2050 , therefore this presents challenges to continue feeding an ever-increasing population is vital. Fish is an important part of human diet and the demand is increasing daily; while the wild fish stocks have remained static or depleted over the past three decades (FAO 2016a). Studies have revealed that Humans consume approximately 80 percent of fish as food, while the remaining 20 percent goes into the manufacturing of products such as fish oil, fertilizers, and animal food. Fisheries and aquaculture are important parts of agriculture which has been found to have positive effect on the country's GDP and has the potential to solve unemployment problems provided that it is optimally managed (Ozigbo et al., 2014).

The African cat fish, Clarias gariepinus (Burchell 1822) is the most popular and widely cultivated species around the globe and is the most smoked species in Nigeria (Aderolu and Akpabio, 2009). Nigeria has been ranked the top producing country in the World followed by the Netherlands, Brazil, Hungary, Kenya, Syrian Arab Republic, South African, Cameroon, and Mali (FAO 2016b). The total production of African cat fish officially reported by FAO is 246,476 tonnes globally during the year 2015 (FAO, 2017). In recent years, Nigeria contributes more than $67 \%$ of the total global production, followed by Uganda, Cuba, Sudan, Hungary, Netherlands, Benin and Brazil (FAO, 2019). Nigeria now produces around 1 million 
metric tonnes of fish per year; with over 750,000 metric tonnes from capture fisheries and roughly 310,000 tonnes from aquaculture. Cat fish being the dominant fish cultured in Nigeria is currently responsible for the major aquaculture output of the country (FAO, 2017). According to Adewumi and Olaleye (2010), the high production of $C$. gariepinus has put Nigeria on a global spotlight in the global aquaculture production. Nigeria is currently the second highest producer of aquaculture products in Africa and the highest producer of African cat fish in Africa and the world at large (FAO, 2017). Though Nigeria is ranked first in cat fish production globally, recent studies have shown that Nigeria ranks third globally for the number of people dependent on coastal fisheries for food and nutrition security, and the demand for fish is growing, alongside growth in population and incomes (Bradley et al. 2020). Also despite Nigeria being the world largest producer of cat fish, its demand for fish remain four times the production and the situation further become worse by pest infestation that cause up to $50 \%$ losses (Ozigbo et al., 2014). Though much attention is being paid to fish preservation to extend its shelf-life and improve fish quality, adequate interest must be shown in the technology of fish processing to meet consumers taste and thereby enhance fish utilization and improved marketing of the catch (Eyo, 2001). Despite the efforts of fish farmers in deploying different preservative methods to extend the shelf life of the fish, Dermestes maculatus still remains a great challenge to the fish industry causing about $50 \%$ infestation in smoked-dried fish (Ozigbo et al., 2014); and due to these devastating effects of the pest, most fish farmers have resorted to using synthetic chemicals like Primiphos to reduce the possible losses. However these chemicals do have deleterious effects on the consumers, hence the need to seek for alternative means of extending the shelf life of these products using a safer means.

\section{MATERIALS AND METHODS OF RESEARCH}

The study was carried out at Entomology laboratory of Federal college of Forestry Jos. Jos North Local Government Area of Plateau State. Jos is located at Northern Guinea Savannah at Latitude $9^{\circ} 55$ and $8^{\circ} 55$ Longitude. It has an average elevation of about $1250 \mathrm{~m}$ above sea level and stands at a height of about $600 \mathrm{~m}$ above the surrounding plain. The average temperature ranges between $21^{\circ} \mathrm{C}$ and $25^{\circ} \mathrm{C}$. Rainy season is usually April to September while the dry season is October to March. The mean annual rainfall is $1260 \mathrm{~mm}$.

Sample collection. The leaf of Cymbopogon citratus was obtained from the Department of Forestry Technology in Federal College of Forestry Jos, while fresh Clarias gariepinus was purchased from Katako Market of Jos North Local Government Area of Plateau State, Nigeria. The leaf of Cymbopogon citratus and the fresh Clarias gariepinus were transported to the Entomology Laboratory of Federal College of Forestry.

Preparation of the Plant Powder. The leaves of Cymbopogon citratus were dried under shade for 14 days to prevent breakdown and loss of phytochemical components as the plant is said to possess volatile oils. The dried leaves were then pulverized using electric blender and then sieved using a fine mesh to obtain fine powder which was then stored in an air tight container.

Insect collection and culture. The stock of the insect was obtained from the heavily infested smoke-dried Clarias gariepinus purchased from fish sellers at Katako market Jos, Plateau State, Nigeria. Uninfested smoke-dried C. gariepinus used for the culturing of the insect was treated in the laboratory by heating in the Gallenkamp oven at $60^{\circ} \mathrm{C}$ for 1 hour and then air dried to prevent mould infestation (Adedire and Lajide, 2000). The treated fish were then weighed to obtain $100 \mathrm{~g}$ which were later placed in three (3) 1 litre jars. Ten (10) unsexed adult Dermestes maculatus were introduced into the jars containing the $100 \mathrm{~g}$ of the fish in order to mate and a moist cotton wool with water was placed beside the infested fish in the jar to aid oviposition. The top of the jar was covered to prevent escape of the insects and allow copulation to commence which usually occurred from 24-48 hours. After 14 days, larvae of $D$. maculatus were observed from the cotton wool and the adults were then carefully removed from the jars and kept in separate jars which were then covered with muslin cloth and maintained under laboratory condition at temperature $30 \pm 2^{\circ} \mathrm{C}$ and relative 
humidity $65 \pm 5 \%$ as described by (Akinwumi et al., 2007). The F1 generations of adult Dermestes maculatus and the larvae obtained from the cultured insect were used for the experiments.

Application of treatments. Six newly emerge adults (0-24hrs) of Dermestes maculatus were introduced into separate plastic jars $(80 \mathrm{~mm}$ depth and $100 \mathrm{~mm}$ in diameter) containing $28 \mathrm{~g}$ of uninfested smoke-dried $C$. gariepinus that had been thoroughly mixed with the plant powder at 2.5, 5.0, 7.5 and $10.0 \mathrm{~g}$. Each experimental set-up was replicated three times. Similar jars in triplicate containing untreated fish and the beetle were used as control experiments. The caps of the plastic jars were perforated and cover with muslin cloth so as to prevent escape of the beetle or entry of other insects while allowing aeration. Adult mortality was recorded at 1, 3, 5 and 7 days after treatment and the percentage mortality was calculated.

To another set of experiments, six third-fourth instar larvae of Dermestes maculatus were introduced into separate plastic jars containing $28 \mathrm{~g}$ of uninfested smoke-dried $C$. gariepinus that has been thoroughly mixed with the plant powder at 2.5, 5.0, 7.5 and $10.0 \mathrm{~g}$. Each of the treatments was replicated three times. Similar jars in triplicates containing untreated fish and the beetles were used as control experiment. Larval mortality was recorded at $1,3,5,7,9,11,13,15,17,19$, and 21 days after treatment and expressed as a percentage.

Data obtained was analyzed using SPSS version 23. The data were subjected to analysis of variance (ANOVA) to determine the differences between effects of the different doses of the treatment plant while means were separated using Duncan multiple range test at $P \leq 0.05$. Adults and larval mortality were expressed as percentages.

\section{RESULTS AND DISCUSSION}

Cymbopogon citratus is characterized by the presence of monoterpene constituents like limonene, citral, elemol, citronellal, 1,8 cineole, citronellol, linalool, geraniol, methylheptenone, b-carophyllene, geranylformate and geranyl acetic acid derivation, among these constituents of lemongrass is only limonene and citronellol has an insecticidal effect in them (Ahmad et al., 2008, Liggins et al., 2004). Limonene according to Hieu et al. (2010) is the main component of essential oil from orange (Citrus sinensis), lemongrass (Cymbopogon citratus) and Japanese pepper (Zanthoxylum piperitum). Bharti et al. (2013) also affirms that apart from Tannins, saponins, flavonoids, alkaloid, phenols, and anthraquinones, the essential oil of lemongrass leaves contain the following: Citral, myrcene, geranial, geraniol, limonene, burneol, citronellol, nerol, neral, a-terpineol, elemicin, caffeic acid, apigenin, luteolin, kaempferol, quercetin, chlorogenic acid and geranyl acetate along with many compounds yet to be identified.

The result in Table 1 revealed the mean mortality of Dermestes maculatus larvae after being treated with different dosages of lemongrass leaf powder. The result revealed that after day 1 and day 3, there was no significant difference between the effects of the different doses. After day 5, 7 and 9, there was a significant difference between the effects of the different doses of the lemongrass powder; while from day 11 to 21 , the effect of the different doses of lemongrass powder did not differ significantly from each other. However when compared to the control experiment, there was a significant statistical differences.

Table 1 - Mean mortality of Dermestes maculatus larvae for different dosages at different days

\begin{tabular}{llllllllllll}
\hline Treatment & Day 1 & Day 3 & Day 5 & Day 7 & Day 9 & Day 11 & Day 13 & Day 15 & Day 17 & Day 19 & Day 21 \\
\hline $2.5 \mathrm{~g}$ & $0.00^{\mathrm{a}}$ & $1.00^{\mathrm{a}}$ & $2.33^{\mathrm{a}}$ & $2.67^{\mathrm{ab}}$ & $3.00^{\mathrm{a}}$ & $3.00^{\mathrm{a}}$ & $3.00^{\mathrm{a}}$ & $4.00^{\mathrm{a}}$ & $4.33^{\mathrm{a}}$ & $4.33^{\mathrm{a}}$ & $4.33^{\mathrm{a}}$ \\
$5.0 \mathrm{~g}$ & $0.33^{\mathrm{a}}$ & $1.33^{\mathrm{a}}$ & $2.67^{\mathrm{a}}$ & $3.00^{\mathrm{a}}$ & $3.00^{\mathrm{a}}$ & $3.33^{\mathrm{a}}$ & $3.33^{\mathrm{a}}$ & $3.67^{\mathrm{a}}$ & $4.00^{\mathrm{a}}$ & $4.67^{\mathrm{a}}$ & $4.67^{\mathrm{a}}$ \\
$7.5 \mathrm{~g}$ & $0.00^{\mathrm{a}}$ & $1.00^{\mathrm{a}}$ & $1.67^{\mathrm{ab}}$ & $2.67^{\mathrm{ab}}$ & $3.00^{\mathrm{a}}$ & $3.67^{\mathrm{a}}$ & $3.67^{\mathrm{a}}$ & $3.67^{\mathrm{a}}$ & $3.67^{\mathrm{a}}$ & $4.00^{\mathrm{a}}$ & $4.33^{\mathrm{a}}$ \\
$10.0 \mathrm{~g}$ & $0.33^{\mathrm{a}}$ & $0.67^{\mathrm{a}}$ & $1.67^{\mathrm{ab}}$ & $2.00^{\mathrm{b}}$ & $2.33^{\mathrm{b}}$ & $2.67^{\mathrm{a}}$ & $3.33^{\mathrm{a}}$ & $3.67^{\mathrm{a}}$ & $3.67^{\mathrm{a}}$ & $4.00^{\mathrm{a}}$ & $4.33^{\mathrm{a}}$ \\
Control & $0.00^{\mathrm{a}}$ & $0.33^{\mathrm{a}}$ & $0.67^{\mathrm{a}}$ & $1.00^{\mathrm{c}}$ & $1.00^{\mathrm{c}}$ & $1.33^{\mathrm{b}}$ & $1.67^{\mathrm{b}}$ & $1.67^{\mathrm{b}}$ & $2.00^{\mathrm{b}}$ & $2.00^{\mathrm{b}}$ & $2.00^{\mathrm{b}}$ \\
SE & 0.21 & 0.37 & 0.33 & 0.21 & 0.15 & 0.3 & 0.33 & 0.35 & 0.45 & 0.49 & 0.47 \\
\hline
\end{tabular}

Means in the same column having the same superscripts are not significantly different from each other. 
The result in Table 2 indicated the mean mortality of adults Dermestes maculatus after being treated with different dosages of lemon grass powder. The result revealed that after day 1 , there was no significant difference between the effects of the different treatments, but from day 3 to 7 was significant differences between the effects of the different doses.

Table 2 - Mean mortality of Dermestes maculatus Adults for different dosages at different days

\begin{tabular}{lllll}
\hline Treatment & Day 1 & Day 3 & Day 5 & day 7 \\
\hline $2.5 \mathrm{~g}$ & $0.00^{\mathrm{a}}$ & $0.00^{\mathrm{a}}$ & $0.00^{\mathrm{b}}$ & $0.00^{\mathrm{c}}$ \\
$5.0 \mathrm{~g}$ & $0.00^{\mathrm{a}}$ & $1.00^{\mathrm{a}}$ & $1.33^{\mathrm{a}}$ & $1.33^{\mathrm{a}}$ \\
$7.5 \mathrm{~g}$ & $0.33^{\mathrm{a}}$ & $0.33^{\mathrm{b}}$ & $0.33^{\mathrm{b}}$ & $0.67^{\mathrm{abc}}$ \\
$10.0 \mathrm{~g}$ & $0.00^{\mathrm{a}}$ & $1.00^{\mathrm{a}}$ & $1.00^{\mathrm{a}}$ & $1.00^{\mathrm{ab}}$ \\
Control & $0.00^{\mathrm{a}}$ & $0.00^{\mathrm{b}}$ & $0.00^{\mathrm{b}}$ & $0.33^{\mathrm{ab}}$ \\
SE & 0.15 & 0.15 & 0.21 & 0.26 \\
\hline
\end{tabular}

Means in the same column having the same superscripts are not significantly different from each other.

The results in Table 3 showed the overall percentage mean mortality of Dermestes maculatus larvae after treatment with different doses of leaf powder of Cymbopogon citratus. The overall result reveals that as the number of days increased, the percentage mean mortality also increased. The result also indicates that overall $2.5 \mathrm{~g}$ and $5.0 \mathrm{~g}$ caused the highest percentage mean mortality while the control caused the least.

Table 3 - Percentage Mean mortality of Dermestes maculatus larvae for different dosages at different days

\begin{tabular}{llllllllllll}
\hline Treatment & Day 1 & Day 3 & Day 5 & Day 7 & Day 9 & Day 11 & Day 13 & Day 15 & Day 17 & Day 19 & Day 21 \\
\hline $2.5 \mathrm{~g}$ & 0.0 & 16.7 & 38.9 & 44.4 & 50.0 & 50.0 & 55.6 & 66.7 & 72.2 & 72.2 & 72.2 \\
$5.0 \mathrm{~g}$ & 5.6 & 22.2 & 44.4 & 50.0 & 50.0 & 55.6 & 55.6 & 61.1 & 66.7 & 77.8 & 77.8 \\
$7.5 \mathrm{~g}$ & 0.0 & 16.7 & 27.8 & 44.4 & 50.0 & 61.1 & 61.1 & 61.1 & 66.7 & 66.7 & 72.2 \\
$10.0 \mathrm{~g}$ & 5.6 & 11.1 & 27.8 & 33.3 & 38.9 & 44.4 & 55.6 & 61.1 & 61.1 & 66.7 & 72.2 \\
Control & 0.0 & 5.6 & 11.1 & 16.7 & 16.7 & 22.2 & 27.8 & 27.8 & 33.3 & 33.3 & 33.3 \\
\hline
\end{tabular}

Table 4 showed the overall percentage mean mortality of adult Dermestes maculatus after treatment with different doses of leaf powder of Cymbopogon citratus. The overall result reveals that as the number days increased, the percentage mean mortality also increased. The result reveals that overall, $5.0 \mathrm{~g}$ and $10.0 \mathrm{~g}$ caused the highest percentage mean mortality while the control caused the least.

Table 4 - Percentage Mean mortality of Dermestes maculatus adults for different dosages at different days

\begin{tabular}{lllll}
\hline Treatment & Day 1 & Day 3 & Day 5 & day 7 \\
\hline $2.5 \mathrm{~g}$ & 0.0 & 0.0 & 0.0 & 0.0 \\
$5.0 \mathrm{~g}$ & 0.0 & 16.7 & 22.2 & 22.2 \\
$7.5 \mathrm{~g}$ & 5.6 & 5.6 & 5.6 & 11.1 \\
$10.0 \mathrm{~g}$ & 0.0 & 16.7 & 16.7 & 16.7 \\
Control & 0.0 & 0.0 & 0.0 & 5.6 \\
\hline
\end{tabular}

The observed mortality in Dermestes maculatus larvae after treatment with lemongrass leaf powder may be due to the presence of limonene found in lemongrass as indicated by Hieu et al. (2010) who reported that limonene is the main component of lemongrass essential oil. The result also collaborated with work of Heibeish et al. (2008) who said limonene is found in at least 15 pesticides and repellent products. The result is further in consonant with Hollingsworth (2005) and Hieu et al. (2010) who said limonene has toxic and repellent properties against several arthropods. Furthermore, the mortality could have been because of the presence of coumarins, tannins, anthraquinone and saponins which had been reported to contribute to the toxicity of the lemongrass (Akande et al., 2011; Ekpenyong et al., 2015).

The results of this finding showed that treating smoked catfish (C. gariepinus) with varying doses of lemongrass leaf powder can protect the fish against Dermestes maculatus. The efficacy of the lemongrass powder on hide beetle was higher when the treatment doses 
were higher. The lemongrass leaf powder was found to have caused $77.8 \%$ mortality in the larvae and $22.2 \%$ mortality in the adult Dermestes when compared with the untreated control that recorded $33.3 \%$ for larvae and $5.8 \%$ for the adult. The results also indicated that almost all the doses of the Cymbopogon citratus powder used caused some significant effects on Dermestes maculatus when compared with the untreated control. Furthermore, the results also indicated that as the time of exposure increased, the mortality of the Dermestes maculatus increased.

\section{CONCLUSION}

The present study shows that leaf powder of lemongrass demonstrated effectiveness in controlling Dermestes maculatus infestation in stored smoke-dried Clarias gariepinus as observed in the results from the results. The effectiveness of this botanical is further buttressed by the fact that even at the lowest dosage; it caused a significant mortality in the larval $D$. maculatus which is the most destructive stage of the pest. Overall, the $5.0 \mathrm{~g}$ performed better where it caused mortality of $77.8 \%$ in the larval $D$. maculatus; therefore lemongrass leaf powder can safely be used to preserve smoke-dried fish against $D$. maculatus infestation during storage coupled with the fact that the lemongrass has many health benefits.

\section{REFERENCES}

1. Adedire, C.O., Lajide L. (2000). Effect of pulverized plant materials on fish damage and growth performance of the fish beetles Dermestes maculatus (Degeer). Entomological Society of Nigeria Occasional Publication. 32: 215-221.

2. Aderolu, A. Z. and Akpabio, V. M. (2009). Growth and economic performance of Clarias gariepinus juveniles fed diets containing velvet bean, Mucuna pruriens seed meal. African Journal of Aquatic Sciences, 34 (2):131-135.

3. Adewumi, A.A. and Olaleye, V.F. (2010). Catfish culture in Nigeria: Progress, prospects and problems. African Journal of Agricultural Research 6:1281-1285.

4. Ahmad, M.A., Hanif, R., Nadeem, M.S., Jamil, M.S., Zafar. (2008). Nutritive evaluation of medicinal plants being used as condiments in South Asian Region. Journal of the Chemical Society of Pakistan, 30 (3): 400-405.

5. Akande, I.S., Samuel, T. A., Agbazue, U. and Olowolagba, B (2011). Comparative proximate analysis of ethanolic and water extracts of Cymbopogon citratus (lemongrass) and four tea brands. Plant Sci. Res., 3 (4): 29-35.

6. Akinwumi, F.O., Fasakin E.A., Adedire C.O. (2007). Toxic and repellence population activities of four plant extracts to Dermestes maculatus Degeer on smoked African mud catfish, Clarias gariepinus [Burchell]. Journal of Entomology, 4(2): 149-154.

7. Bharti, S.K., Kumar, A., Prakash, O., Sharma, N.K., Krishnan, S. (2013). Essential Oil of Cymbopogon citratus against Diabetes: Validation by in vivo Experiments and Computational Studies. Scientific Reports, 2(3):1-9.

8. Bradley, B. Byrd, K.A. Atkins, M. Isa, S. Akintola, S.L. Fakoya, K.A. Ene-Obong, H. Thilsted, S.H. (2020). Penang, Malaysia: World Fish. Program Report: 2020-06.

9. Ekpenyong, C.E., E. Akpan, A. Nyoh (2015). Ethnopharmacology, phytochemistry, and biological activity of Cymbopogon citratus (DC.) Stapf extracts Chinese J. Nat. Med., 13: 321-337.

10. Eyo, A.A. (2001). Fish processing Technology in the Tropics. National Institute for Freshwater, Fisheries Research (NIFFR), New Bussa, 37-39.

11. FAO (2016a). The State of World Fisheries and Aquaculture-Contributing to food security and nutrition for all. Fisheries and Aquaculture Department, Food and Agriculture Organization of the United Nations, Rome pp: 200.

12. FAO (2016b). Cultured Aquatic Species Information Programme: Clarias gariepinus. Fisheries and Aquaculture Department, Food and Agricultural Organization of the United Nations, Rome. 
13. FAO (2017). Fishery and Aquaculture Statistics. Global aquaculture production 19502015 (FishstatJ). In: FAO Fisheries and Aquaculture Department. Rome.

14. FAO. (2019). Fishery and Aquaculture Statistics. Global aquaculture production 19502017 (FishstatJ). FAO Fisheries and Aquaculture Department [online]. Rome: Food and Agriculture Organization of the United Nation.

15. Heibeish, A., M.M.G., fouda, I.A., Hamdy, S. M-El-Shawy and F.A. Abdel-mohdy. (2008). Preparation of durable insect repellent cotton fabric: limonene as insecticide. Carbohydrate polymers 74:268-273.

16. Hieu, T.T., S. I. Kim, H. W, Kwon, Y. J. Ahn. (2010). Enhanced repellency of binary mixture of Zanthoxylum piperitum pericarp steam distillate or Zanthoxylum armatum seed oil constituents and collophyllum and inophyllum nut oil and their aerosols to Stomaxys calutrans. pest management sciences, 66:1191-1198.

17. Hollingsworth, R.G. (2005). Limonene, a citrus extract, for control of mealybugs and scale insects. Journal of Economic Entomology 98:772-779.

18. Liggins, H.M., Burt. (2004). Paclitaxel-loaded poly (L-lactic acid) microspheres 3: blending low and high molecular weight polymers to control morphology and drug release. International journal of pharmaceutics. 282(1): 61-71.

19. Ozigbo, E., Anyadike, C., Adegbite, O. and Kolawole, P. (2014). "Review of Aquaculture Production and Management in Nigeria. American Journal of Experimental Agriculture 4(10): 1137-1151. 